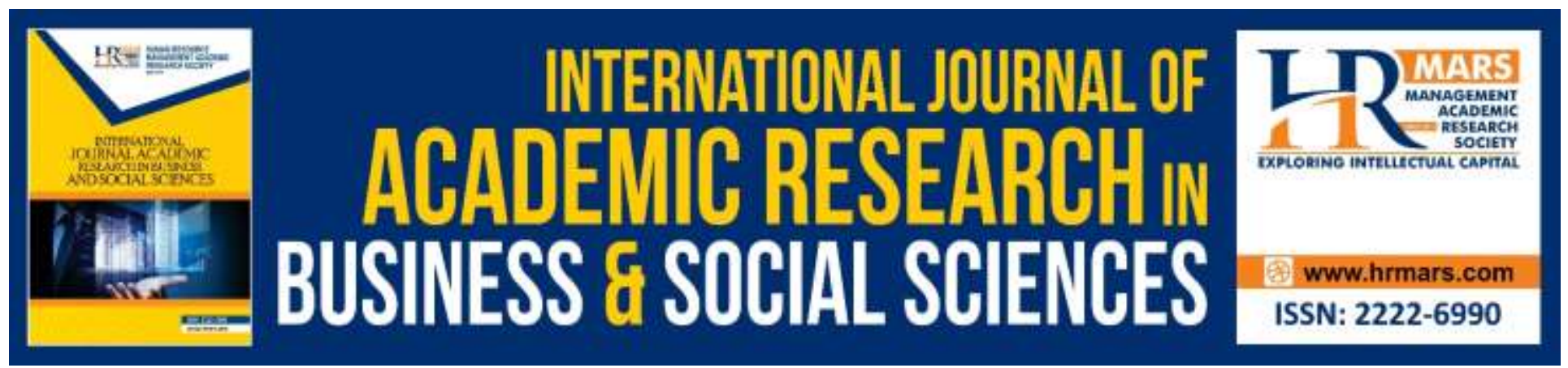

\title{
Crisis Communication Management Strategies in MH370 Crisis with Special References to Situational Crisis Communication Theory
}

Afiqah Farzana Othman, Siti Zanariah Yusoff

To Link this Article: http://dx.doi.org/10.6007/IJARBSS/v10-i4/7118

DOI:10.6007/IJARBSS/v10-i4/7118

Received: 23 February 2020, Revised: 18 March 2020, Accepted: 28 March 2020

Published Online: 10 April 2020

In-Text Citation: (Othman \& Yusoff, 2020)

To Cite this Article: Othman, A. F., \& Yusoff, S. Z. (2020). Crisis Communication Management Strategies in MH370 Crisis with Special References to Situational Crisis Communication Theory. International Journal of Academic Research in Business and Social Sciences, 10(4), 172-182.

Copyright: (C) 2020 The Author(s)

Published by Human Resource Management Academic Research Society (www.hrmars.com)

This article is published under the Creative Commons Attribution (CC BY 4.0) license. Anyone may reproduce, distribute, translate and create derivative works of this article (for both commercial and non-commercial purposes), subject to full attribution to the original publication and authors. The full terms of this license may be seen

at: http://creativecommons.org/licences/by/4.0/legalcode

Vol. 10, No. 4, 2020, Pg. 172 - 182

http://hrmars.com/index.php/pages/detail/IJARBSS

JOURNAL HOMEPAGE

Full Terms \& Conditions of access and use can be found at http://hrmars.com/index.php/pages/detail/publication-ethics 


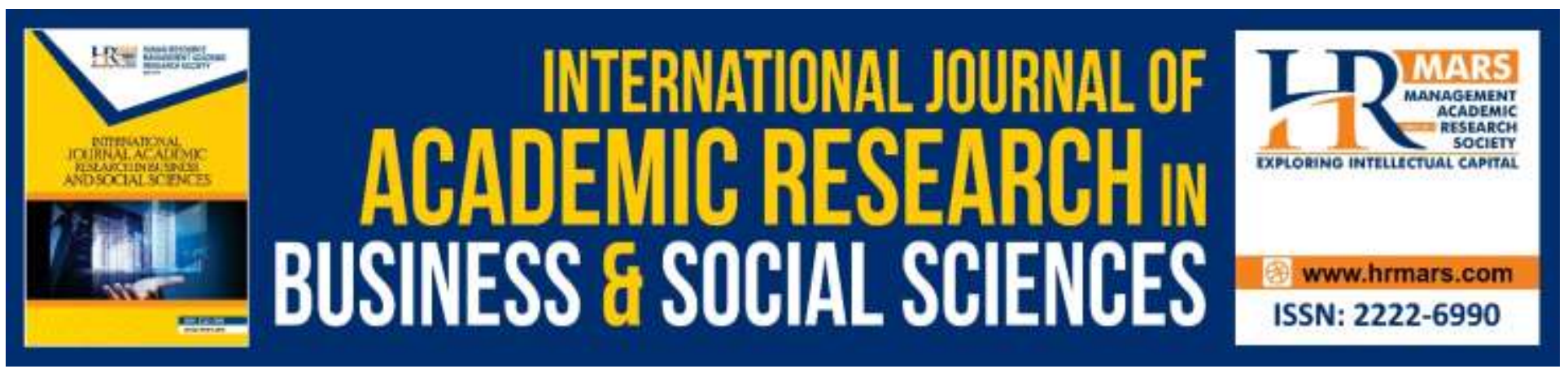

\title{
Crisis Communication Management Strategies in MH370 Crisis with Special References to Situational Crisis Communication Theory
}

\author{
Afiqah Farzana Othman, Siti Zanariah Yusoff \\ Centre of Modern Languages and Communication, Faculty of Language and Communication \\ Universiti Sultan Zainal Abidin, 21300 Kuala Nerus, Terengganu \\ Email: afiqahothman595@gmail.com zanariahyusoff@unisza.edu.my
}

\begin{abstract}
All businesses in the world are vulnerable to the crisis that can give a damaging impact on the organization's reputation. The peculiar disappearance of flight MH370 has been one of the most highlighted and debated crises in the global perspectives, leaving Malaysia Airlines, the carrier, in a tangled situation. This study aims to bridge the gap in research and provide insights of crisis management strategies employed by Malaysia Airlines in times of the crisis. The Situational Crisis Communication Theory (SCCT) is used as a framework in the analysis to explore the alignment of crisis management operated by the airlines and the recommendations of managing a crisis as guided in theory. The methodology used for this study is the qualitative approach. Hence, the data for this study was obtained from a set of fifteen media statements, six newspaper articles and four website articles covering on $\mathrm{MH} 370$ crisis have been analyzed using the content analysis approach. It was found that the airline was somehow successful in handling the families of victims but not in delivering the crisis messages as it obeyed and violated the recommendations in the SCCT. It concludes that MAS was fairly productive in implementing strategies as it shows the bad and good ways of handling a major disaster.
\end{abstract}

Keywords: Crisis Communication, Crisis Management, Crisis Response Strategies, Situational Crisis Communication Theory, MH370

\section{Introduction}

In crisis communication management, the potential damage a crisis can impose on an organization, its stakeholders and an industry is the threat. In correspondence to Coombs (2007), there are three related threats that can be generated by a crisis; i) public safety, ii) financial loss and iii) reputation loss. In essence, the ultimate concern in a crisis has to be the public safety. The damage from a crisis will be intense if the organization fails to address public safety. Following that, reputation and financial concerns will be significantly affected if the safety is not well considered. 
INTERNATIONAL JOURNAL OF ACADEMIC RESEARCH IN BUSINESS AND SOCIAL SCIENCES Vol. 10, No. 4, April, 2020, E-ISSN: 2222-6990 @ 2020 HRMARS

In conjunction with that, business like aviation industry does not only engage in an environment that is erratic, but also vulnerable to crisis. The airline industry is occasionally struggling with the crisis which does not follow the standard crisis management pattern because of the possibility they might endure sudden crisis that demands immediate attention and response despite the strict security procedures outlined for the aviation industry (Alexander, 2013). For that reason, aviation companies must gear up to respond expeditiously and effectively. The way an aviation company reacts to a crisis not only can affect the upshot of the crisis itself, but it also can have a vast impact on the company's reputation and survival. As a matter of fact, in 2014, MH370 flight was disappeared from the radar soon after it departed in less than an hour scheduled from Kuala Lumpur to Beijing. The crisis endured by Malaysian Airline System (MAS) Berhad or currently known as Malaysia Airlines Berhad (MAB) has become one of the high-profiled tragedies in Malaysia. Disastrously, the first original news responding to the misfortune of flight $\mathrm{MH} 370$ was released approximately five hours after losing communications and radar was disconnected from the MH370 flight (Eyde, n.d.). The situation has created a credibility gap due to the deferment response from the airline company which led Malaysia Airlines' crisis communication operation an unparalleled challenge.

McClellan (2014) stated that the company has not been speaking with one voice and been shrieking like an uncoordinated choir which certainly can lead to confusion. He adds that the information supplied by the company was contradicting with each other. The company's response to the disappearance of $\mathrm{MH} 370$ is one of the bad examples of crisis communication management ever seen. Notably, it is opposing with one of the crisis communication management theories, the Situational Crisis Communication Theory (SCCT) which claims that speaking with one voice in a crisis is a way to maintain accuracy (Coombs, 2007).

Additionally, the public relations team also exhibited bad performance in failing to communicate and prioritize the concerns of families' victims (Xuan et al., 2017). Najib Razak, former Prime Minister of Malaysia, even confessed in an article for the Wall Street Journal that in the first few days after the plane disappeared, they were so focused on trying to find the aircraft that they did not prioritize the communications. The statement shows that despite it is undeniable this tragedy was unprecedented, Malaysia Airlines indeed lost control when the crisis hit. In accordance to that, Malaysia Airlines was greatly criticized for its poor crisis communication after the plane MH370 went missing and even for not managing the situation with more lucidity and promptness (Sudhaman, 2014).

By right, an accurate and consistent message is more trustable and conceivable. Coombs (2014) states that, to speak with a single voice, be quick and try to have the initial responses within the first hour are essential to sustain control over the integrity and authenticity of information to avert a blunder that might harm the organization's reputation. This research is significant because it investigates the crisis communication handled by Malaysia Airlines in many different aspects; delivery of information, handling of victim's families, crisis response strategies and the chosen communication channels, thus this study can help achieve some of the gaps that exist in literature (Ashari, Ahmad \& Samani, 2017; Adebayo, 2017). Besides, by referring to the SCCT, this study stays grounded to the crisis communication management and offers possible suggestions on how to apply the theory into a real-life crisis setting. Moreover, in Malaysia, crisis management is a new field to be studied, yet it is very pertinent in demand of today's world as it offers communications, journalism, international studies and writing in one umbrella. As mentioned by Moore (2007), the knowledge of crisis 
management is extremely crucial as it is designed to blend all those elements to bring the light on handling the potential crisis situations and deciding how to deal with them.

Hence, the present study aims to evaluate how far they have succeeded in managing their crisis communication. It will be based on one of the crisis management theories, Situational Crisis Communication Theory (SCCT). The study fills the gap as it extends the research by examining the strategies executed through the news media platform on how the airlines react to the crisis and communicate with the stakeholders. This study attempts to answer the research questions as follow:

- What are the styles of crisis communication executed by MAS in the MH370 flight crisis?

- Are the strategies implemented by MAS align with the crisis communication management theory, SCCT?

\section{Crisis}

A crisis has been sufficiently defined in the crisis communication management literature. There are numerous definitions of crisis but most of them agree that a crisis can menace the organization's reputation. As claimed by Coombs (2007), crisis is a sudden and unexpected event that threatens to disrupt an organization's operations and poses both financial and reputational threat. In addition, the definition mentioned by Fearn-Banks (2001), talks about the stakeholders in which a crisis is a major occurrence with a potentially negative outcome affecting an organization as well as its publics, services, products and/or good name. It interrupts normal business transactions and can, at its worst, threaten the existence of the organization.

\section{Crisis Management}

The most common practice for dealing with crises in organisations is called crisis communication management. By definition, crisis communication management is a process designed to prevent or lessen the damage a crisis can inflict on an organization and its stakeholders (Coombs 2007). In Handbook of Public Relations book, Fearn-Banks (2001) considers that crisis communication management can be defined as a process of strategic planning for a crisis or negative turning point, a process that removes some of the risk and uncertainty from the negative occurrence and thereby allows the organization to be in greater control of its own destiny.

\section{Crisis Communication}

Planning cannot prevent every crisis and at times, corporations must directly respond to corporate crises (Benoit, 2004, cited in Adebayo, 2017). Fearn-Banks (2001) defines crisis communication as the dialog between the organization and its publics prior to, during, and after the negative occurrence. She explains that the strategies and tactics used are designed to minimize damage to the image of the organization. In the Handbook of Crisis Communication, Coombs \& Holladay (2012) defines crisis communication as the collection, processing, and dissemination of information required addressing a crisis situation. In addition, crisis communication includes the collection and processing of information for crisis team decision making along with the creation and dissemination of crisis messages to people outside of the team. 
INTERNATIONAL JOURNAL OF ACADEMIC RESEARCH IN BUSINESS AND SOCIAL SCIENCES Vol. 10, No. 4, April, 2020, E-ISSN: 2222-6990 @ 2020 HRMARS

\section{Crisis Response Strategies (CRS)}

The CRS were later categorized into two big strategies; primary CRS and secondary CRS. Primary CRS includes deny, diminish and rebuild (Coombs \& Holladay, 2002). Each facet represents a set of strategies that share same communicative goals, reflecting the amount of responsibility an organization seems to accept for a crisis and the amount of aid that it seems to provide for the victims of the disaster. The secondary strategies which consist of bolstering CRS are only supplemental to the primary strategies. Because these strategies focus on the organization, they would seem rather egocentric if used alone (Coombs 2006).

Deny strategy is suggested to be used to omit any connection between the organization and the crisis. This type of CRS gives no reputational harm to the corporation as long as the organization free from any linkage to the cause of the crisis. On the other hand, the diminish CRS argue that the disaster is not as bad as it seems or that the organization lacked control over the crisis. Lastly, the rebuild strategy attempts to risen the organization's reputation by providing material and/or symbolic forms of aid to the victim. It can be used as the organization's effort to take positive actions to offset the crisis by providing the compensation in the form of gifts and money or apology to indicate the organization takes full responsibility for the stakeholders as well as seeking for the forgiveness (Coombs, 2007).

\section{Situational Crisis Communication Theory (SCCT)}

The SCCT is one of the two most widely accepted and used crisis response (Adebayo, 2017) which is a model that uses an evidence-based strategy. Developed and refined by Timothy Coombs, this theory gives a symbolic representation of the organisation's historical performance and its relationship building approach by combining the rhetorical, impression management and image restoration concepts together to help predict how stakeholders react to the crisis (Coombs, 2006).

\section{Research Methodology}

This research aims to gain in-depth fragmentation on how Malaysia Airlines handled their crisis when the MH370 flight went missing. This study adopts a qualitative research to analyse the appropriateness of the strategies implemented by MAS during the crisis based on the crisis communication management theory, SCCT. This research is based on the analysis of Malaysia Airlines' crisis communication management. Therefore, the method used to obtain data for this study is document analysis approach. The news media platform is chosen to aid in achieving the goal of this study. As MH370 received attention from the members of the global community, fifteen media statements, six online newspaper articles, and three news blogs articles are selected for conducting the study.

The chosen media statements are from the first days of the crisis; March 8th until March 12th, 2014. In this period, Malaysia Airlines released fifteen (15) media statements which can be said as a realistic amount of data to be studied in this paper. Besides, the online newspaper articles are chosen to identify the styles implemented by the airlines in the crisis. Correspondingly, articles from the online newspaper should match the information provided in Malaysia Airlines' media statements. Note that the articles from the online newspaper are taken for a few weeks of time to be the extra information to investigate the handling of the crisis. Furthermore, the online newspaper articles are chosen as they are published without any interference from the Malaysia Airlines officers themselves. Thus, 
INTERNATIONAL JOURNAL OF ACADEMIC RESEARCH IN BUSINESS AND SOCIAL SCIENCES

Vol. 10, No. 4, April, 2020, E-ISSN: 2222-6990 @ 2020 HRMARS

more honest and straightforward articles will be examined to conduct the study. Hence, the articles cover the period from March 8th until March 25th, 2014.

Last but not least, articles from the news blogs are selected as many international crisis strategists provide judgments on how Malaysia Airlines handle the crisis and their stakeholders. Hence, an explanation of the way MAS managed the tragedy will be analysed from the news blogs articles starting from the March 13th to March 21st, 2014.

\section{Findings and Discussion}

This section will include the findings and discussions to answer the research question. Based on thorough analysis, four themes were found to facilitate the discussions. They are the initial response, spokesperson, diminish crisis response strategies (justification), and rebuild CRS (compensation and apology).

\section{The Initial Response}

As recommended in SCCT, Coombs stated the initial crisis response procedures emphasize on three points; 1 ) be quick, 2) be accurate, and 3) be consistent. Be quick rather simple as it is just to respond in the first hour after the crisis occurs. He then added the rationale of being quick is the need for the organization to tell its side of the story first to the stakeholders before the other party has chances to do so. In this case, the stealing thunder approach falls under this scope where it is a matter of timing involving the disclosure of information about a crisis (Coombs, 2007).

In that respect, MAS notified the public regarding the lost connection of the MH370 flight with the Subang Traffic Air Control on March 8, 2014 (MH370 Wiki, 2014). The strategy, however, violated the SCCT recommendations since the airlines apprised the public after five hours the flight disconnected from the radar. This action contributed to the negative impact towards the organization because Malaysia Airlines took too many hours to notify the public especially the families of passengers on board that the jet disappeared without a trace.

When a crisis occurs, Coombs (2007) stated that people curious to know what happened and the news media will grab the charge to fill the information vacuum and wanting to be a key source of initial crisis information. If the organization enduring the crisis does not communicate with the news media, other people will be happy to talk to the media on behalf of the organization (Coombs, 2007). These people unfortunately, may have inaccurate information or may try to use the crisis as an opportunity to attack the organization. Just like the $\mathrm{MH} 370$ case, it is worried if there were any other parties will "do the job" before the airline itself has the chance to do so and the worst case scenario could happen if the victims' families heard the news from some other people first.

\section{Spokesperson in Organizational Communication}

The choice of the spokespeople in a crisis is critical as the spokesperson are those who will speak and liaise with the different stakeholders in the occurrence of a crisis (Cloudman \& Hallaman, 2006) cited in (Adebayo, 2017). As mentioned in the early discussion, the organizations must respond swiftly when the crisis breaks. Thus, to act quickly, a spokesperson must be an autonomous (Marra, 1998), experienced, and a media-trained person who is well briefed, prepared, and self-controlled (as cited in Dutton et al., 2004). 
This claim is suggested in the SCCT guidelines where a visible spokesperson is a part of effective crisis communication management (Coombs, 2007). In this respect, Malaysia Airlines obeyed the SCCT guidelines as they decided to make sure that its top management was visible to the public in managing the crisis. The dominant figure of the organization, the GCEO, Ahmad Jauhari Yahya led a press statement on MH370 tragedy on the first day and was a visible spokesperson for the organization in their time of crisis. His statement complied with the content recommendations of a crisis response (Coombs, 1999) cited in (Adebayo, 2017) as it consisted information about the crisis, their crisis communication management efforts, and compassion to the victims of the tragedy.

However, speaking with one voice does not mean only one person presents the organization in the duration of a crisis. Coombs (2014) emphasized the public relations department to play more of a support role rather than being "the" spokespersons. The crisis team needs to distribute information so that different people can still convey a consistent message. In the MH370 case, Malaysia Airlines not only positioned Ahmad Jauhari Yahya as the spokesperson but they diversified the voices for the crisis. Not because Ahmad Jauhari Yahya was not the best choice to be the face of the crisis, but it was because Malaysia Airlines was the government-owned aviation company (Centre of Aviation, 2018). The Prime Minister of Malaysia, Najib Razak and Transport Minister, Hishammuddin Hussein were made visible within the first 24 hours of the crisis occurrence to address the public and feed them on the crisis information (MH370 Wiki, 2014) that was available based on what is known and what is being done in managing the crisis and its victims (Coombs, 2014) cited in (Adebayo, 2017).

\section{Diminish Crisis Response Strategies (Justification)}

Malaysia Airlines began to use the diminish crisis response strategy through the first media statement where they notified the loss of contact with the plane (MH370 Wiki, 2014) thus confirmed that this circumstance could be interpreted as something beyond the power of the organization, neither would they intentionally harm the passengers, their crew and the plane itself.

Another example of the implementation of diminish CRS was when Malaysia Airlines moved swiftly forward to justify the speculation spread in the social media regarding the flight has emergency landed in Nanning, China (NBC News, 2014). Hishammuddin made the justification that the claim was incorrect and urged the public especially the media not to escalate the fake news as it can worsen the search and rescue mission of the lost jet (MH370 Wiki, 2014). The diminish strategy was adopted as the airlines knew how the power of media could affect the crisis communication in the tough time. Moreover, if the public's perception is negative towards the crisis, the airline can immediately be blamed for the crisis. It is because plane accidents are a magnet of attention as the general public deliberately insists to know the cause of the accident (Cobb \& Primo, 2003) as cited by Zafra \& Maydell (2018). Thus the high level of communication with its stakeholders is needed in this crisis.

\section{Rebuild CRS (Compensation \& Apology)}

As recommended in the SCCT, Malaysia Airlines has adopted the rebuild strategy as expected in the airline industry that involves plane accidents by compensating the families of passengers on board. It was an astonishing action employed by MAS as discussed in the previous section where Malaysia Airlines provided an abundant amount of aids towards the families such as immediate financial aid, travel facilities, accommodation, meals, and hotel. It can be observed that the compensation strategy employed by MAS was as a form of a full responsibility even though the incident happened was out 
of their control; it still required a strong crisis responsibility. In accordance with Coombs (2014), the outcomes of strong crisis responsibility will protect the reputation and purchase intention. It is because, in times of crisis, none of the organizations in the world would want to lose their customers. Thus, a victim focus is what will help to reduce the amount of damage an organization suffers from the crisis (Coombs, 2014).

Besides, rebuild CRS also involves the corporation to express sympathy and to explain what the organization is doing to prevent a repeat of the crisis (Coombs, 2007). It (apology) takes part in the SCCT as an apology expresses regret over the event and requests forgiveness as well as to restore the organization's eroded reputation (Adebayo, 2017). Coombs (2012) claimed an apology is strongly recommended because of its ability to rebuild trust and it should significantly help to repair the damage done by the crisis. In this case, Malaysia Airlines was successful in conveying how they portrayed the emotions as mentioned in the previous section, MAS did not directly express their forgiveness towards the public, but some of the words showed that the airlines were deeply regretting over the bizarre disappearance.

For instance, Ahmad Jauhari Yahya communicated in his statement, "To the families of the passengers on board MH370, we share your pain and anxiety. They are of the MAS family, and we are deeply affected by this unfortunate incident" (MH370 Wiki, 2014). Ahmad Jauhari highlighted the use of word "anxiety" to indicate the feeling of worry, nervousness, and unease about the unknown whereabouts of the jet. Anxiety creates a strong need for adjusting information, particularly the messages that can help stakeholders cope emotionally with the crisis. More research is necessary to include the value of stakeholder emotions into the formulation of crisis response strategies (Coombs, 2014). To add, Malaysia Airlines also obeyed the recommendations in the SCCT where the corrective actions and trauma counseling are well provided by the airlines as discussed in the first research question. Corrective actions, as claimed by Coombs (2007) are taken when the company accepts the responsibility of the wrongful acts and corrects the problem as their fault. It is aimed to reduce the offensiveness of the crisis act.

\section{Conclusion}

Based on the presented findings, this study concludes that MAS' crisis communication management was reasonably functional regardless of depicting some unapologetically loopholes in the way they handled the crisis in the earliest times of tragedy. It showed that even though MAS did not rise to the theoretical definition of success and was not able to reach the momentum in operating the crisis, the airline company, however, survived the crisis. For instance, it is undeniable the airlines received criticism from the worldwide professional experts as they were judged because many of the media releases focused on dispelling myths and rumours circulating in the absence of information even though numerous statements were issued since it lost contact with the plane. It had grown the frustration among the affected stakeholders because the attentions were always diverted.

However, MAS succeeded in ways they managed the families' care. Malaysia Airlines conducted an excellent job in assisting the devastated families to ensure they have access to around-the-clock support. The comprehensive support program, which provided the caretakers since the day one of the crisis, managed to engage a really strong bond with the family members as they compassionately offered support, counsel, and care. The company also has fulfilled the responsibility in assigning the financial aids to the families of victims. 
In the respect of the crisis management theory, it can be concluded the airlines have obeyed and violated the guidance recommended in SCCT to survive a crisis. For instance, Malaysia Airlines obeyed the theory by employing diminish strategy, mainly justification most of the time to show its credibility to the stakeholders and at the same time, reduced the organization's connection to the crisis. On the other aspect, Malaysia Airlines violated the theory as its initial response took few hours to notify the public regarding the disappearance of $\mathrm{MH} 370$ flight from the supposed timeline. It is clearly contradicted from what SCCT has suggested for the organization to be quick in notifying the public about a certain crisis as the necessity of an immediate response to a crisis may inhibit the organization's ability to access stakeholders.

This research provides theoretical implication in bridging a gap between academic and industrial practice and a gap between crisis communication research and contextual use of crisis communication with a focus on a developing country like Malaysia (Adebayo, 2017). Practically, this research is not only limited to the academics but also provides practical implications on how to govern crisis especially a complex one as the study was able to propose insights into how Malaysia Airlines managed their crisis, a procedure that can be replicated for crisis communication management. In respect to this matter, the results from this analysis provide support to the recommendation of crisis scholar concerning crisis communication best practices as MAS was able to manage the disaster by showing compassion to the traumatized families and an adaptable crisis management plan and policy.

Taking into account regarding MAS' crisis communication management, expansion of this study is required to investigate whether Malaysia Airlines has the crisis communication management plan prepared before any disaster strikes in concerning why MAS delayed for several hours before communicating to the public about the lost contact with the plane and later released inconsistent information to the stakeholders. This type of information only can be assessed through internal contact or interview session with the management team of Malaysia Airlines to know if it was an internally or externally factor that affected their prior crisis plan and crisis communication strategy. Besides, future research may be conducted to investigate the crisis endured by other organizations in different angle such as the perspectives of public view using the quantitative research design since this study adopts the qualitative research approach.

\section{References}

Adebayo, O. (2017). The Application of Facebook to Crisis Communication Management: A Case Study of Malaysia Airlines. Retrieved from http://usir.salford.ac.uk/42319/

Agnes, M. (2014). The Use of Hashtags in Your Crisis Communications. Retrieved from https://melissaagnes.com/the-use-of-hashtags-in-your-crisis-communications/

Ashari, N., Ahmad, D., \& Samani, M. (2017). Crisis Response Strategy and Crisis Types Suitability: A Preliminary Study on MH370. Retrieved from https://www.shsconferences.org/articles/shsconf/pdf/2017/01/shsconf_icome2017_00037.pdf

Alexander, D. (2013). Volcanic Ash in the Atmosphere and Risks for Civil Aviation: A Study approach: Sage.

Bailey, B. (2016). The Case for Pilot Zaharie Ahmad Shah's Hijack of Flight MH370. Retrieved from https://www.theaustralian.com.au/news/inquirer/the-case-for-pilot-zaharie-ahmad-shahshijack-of-flight-mh370/news-story/955ed1c640c91e85a9f660fdf7ed5248 
INTERNATIONAL JOURNAL OF ACADEMIC RESEARCH IN BUSINESS AND SOCIAL SCIENCES Vol. 10, No. 4, April, 2020, E-ISSN: 2222-6990 @ 2020 HRMARS

Branigan, T., \& Farrell, P. (2014). MH370: Relatives of Chinese Passengers Protest at Malaysian Embassy in Beijing. The Guardian. Retrieved from https://www.theguardian.com/world/2014/mar/25/mh370-relatives-chinese-passengersmalaysian-embassy

Centre for Aviation. (2018). Retrieved from https://centreforaviation.com/

Claeys, A., Cauberghe, V., \& Vyncke, P. (2010). Restoring Reputations in Times of Crisis: An Experimental Study of the Situational Crisis Communication Theory and the Moderating Effects of Locus of Control. Elsiver. Retrieved from

http://citeseerx.ist.psu.edu/viewdoc/download?doi=10.1.1.456.9889\&rep=rep1 \&type=pdf

Coombs, T. (2006). The Protective Powers of Crisis Response Strategies: Managing Reputational Assets during a Crisis. Journal of Promotion Management, 12 . doi: doi:10.1300/J057v12n03_13

Coombs, T. (2007). Crisis Communication Management and Communications. Retrieved fromhttp://www.facoltaspes.unimi.it/files/_ITA_COM/Crisis_Management_and_C ommunications.pdf

Coombs, W., \& Holladay, S. (2002). Helping Crisis Managers Protect Reputational Assets: Initial Tests of the Situational Crisis Communication Theory. SAGE. doi: 10.1177/089331802237233

Coombs, T., \& Holladay, S. (2012). The Handbook of Crisis Communication [Ebook]. Wiley-Blackwell. Retrieved from https://books.google.com.my/books

Dutton, J., Frost, P., Worline, M., Lilius, J., \& Kanov, J. (2002). Leading in Times of Trauma. Retrieved from https://hbr.org/2002/01/leading-in-times-of-trauma

Fearn-Banks, K. (2001). Handbook of Public Relations [Ebook]. SAGE Publisher. Retrieved from http://sk.sagepub.com/reference/handbook-of-public-relations

MH370 Wiki. (2014). Retrieved from https://www.mh370wiki.net/wiki/Statements:Day_004

NBC News. (2014). Social Media Spread False Reports of Safe Landing. Retrieved from https://www.nbcnews.com/storyline/missing-jet/social-media-spread-false-reports-safelanding-n48081

New Straits Times. (2014). MH370: MAS could not have been prouder of its caregivers. Retrieved from http://www.asiaone.com/malaysia/mh370-mas-could-not-have-been-prouder-its-caregivers

Rensburg, A., Conradie, P., \& Dondolo, D. (2017). The Use of the Situational Crisis Communication Theory to Study Crisis Response Strategies at a University of Technology, ISSN 2415-0525. doi: https://dx.doi. org/10.18820/24150525/Comm.v22.5

Richards, M. (2014). Malaysia Airlines' 'dark site'. Retrieved from http://blog.marginmedia.com.au/Our-Blog/bid/100379/Malaysia-Airlines-dark-site

Shankar, S. (2014). Malaysia Criticized for Not Handling The Missing Flight MH370 Situation With More Transparency and Promptness. Retrieved from https://www.ibtimes.com/malaysiacriticized-not-handling-missing-flight-mh370-situation-more-transparency-promptness1561122

Sudhaman, A. (2014). Malaysia Airlines Calls in Ketchum for MH370 Crisis PR Counsel. Retrieved 22 April 2018, from https://www.holmesreport.com/latest/article/malaysia-airlines-calls-inketchum-for-mh370-crisis-pr-counsel 
INTERNATIONAL JOURNAL OF ACADEMIC RESEARCH IN BUSINESS AND SOCIAL SCIENCES Vol. 10, No. 4, April, 2020, E-ISSN: 2222-6990 @ 2020 HRMARS

Thomas, N. (2014). Angry Chinese want information on missing Malaysia Airlines flight. Retrieved from https://www.reuters.com/article/us-malaysia-airlines-crash-china/angry-chinesewant-information-on-missing-malaysia-airlines-flight-idUSBREA2709E20140308

Xuan, L., Wei, B., \& Hoe, A. (2017). Case Study A of Malaysia Airlines Crisis Management of Missing Flight Mh370. Retrieved 21 April 2018, from https://abelprblogforhumans.wordpress.com/2017/03/03/case-study-a-ofmalaysia-airlines-crisis-management-of-missing-flight-mh370-by-leong-jia-xuan005052-benjamin-allen-ewe-zai-wei-005032-alvin-lim-wai-hoe-005039-sam-limjeng-xian-005064/

Yen, C. (2014). Social Media Reactions to MH370 [Blog]. Retrieved from https://blog.tailwindapp.com/social-media-reactions-to-mh370/

Zafra, N., \& Maydell, E. (2018). Facing the information void: A case study of Malaysia Airlines' media relations and crisis communication during the $\mathrm{MH} 370$ disaster. Academia. Retrieved from https://www.academia.edu/36636009/Facing_the_information_void_A_case_s tudy_of_Malaysia_Airlines_media_relations_and_crisis_communication_duri ng_the_MH370_disaster 